MINERALOGIA, 46, No 1-2: 29-40 (2015)

Original paper

\title{
Distribution of phenols related to self-heating and water washing on coal-waste dumps and in coaly material from the Bierawka river (Poland)
}

\author{
Ádám Nádudvari ${ }^{1 *}$, Monika J. Fabiańska ${ }^{1}$, Magdalena Misz-Kennan ${ }^{1}$ \\ ${ }^{1}$ University of Silesia, Faculty of Earth Sciences, Będzińska 60, 41-200 Sosnowiec, Poland \\ adam17183@gmail.com \\ * Corresponding author
}

Received:, April 1, 2016

Received in revised form: May 23, 2016

Accepted: July 30, 2016

Available online: September 25, 2016

Abstract. Several types of coal waste (freshly-dumped waste, self-heated waste and waste eroded by rain water), river sediments and river water were sampled. The aim was to identify the types of phenols present on the dumps together with their relative abundances. Gas chromatography-mass spectrometry (GC-MS) analyses of a large number of samples (234) statistically underpin the phenol distributions in the sample sets. The largest average relative contents (1.17-13.3\%) of phenols occur in the self-heated samples. In these, relatively high amounts of phenol, C1- and C2-phenols reflect the thermal destruction of vitrinite. In fresh coal waste, C2- and C3-phenols that originated from the bacterial/fungal degradation and oxidation of vitrinite particles are the most common (0.6 rel.\%). Water-washed coal waste and water samples contain lower quantities of phenols. In the river sediments, the phenols present are the result of bacterial- or fungal decay of coaly organic matter or are of industrial origin.

Key-words: coal waste, GC-MS, phenols, water-washing, self-heating, fluvial transport

\section{Introduction}

Coal waste dumps are a typical element of the landscape in the Upper Silesian Coal Basin (USCB), Poland. Thus, the nature of the chemical compounds that can be leached from these dumps into their surroundings is a matter of some interest. Several processes such as biodegradation, water-washing and self-heating occur in these dumps. All are 
processes that make potentially harmful compounds available for later transport out of the dumps.

The paper focuses on the distribution and general types of phenols related to their possible origin in selected coal-waste dumps and in coaly material in river sediments. Coalwaste dumps (or coal waste that has undergone self-heating) contain phenols related to the composition of vitrinite (Skręt et al. 2010; Misz-Kennan 2010; Misz-Kennan, Fabiańska 2010, 2011). As phenols easily dissolve in water, they are prone to leaching. Potential environmental hazards of phenols are related to their toxicity; they irritate skin and cause necrosis, damage kidneys, liver, muscle and eyes, and are carcinogenic (Clayton, Clayton 1994; EPA 2000; Michałowicz, Duda 2007). Phenols are widespread pollutants. They are introduced into natural water resources in the effluents of industrial chemical plants involved with, e.g., phenol manufacturing - coal tar, pharmaceuticals, resins, paints, dyes, textiles, wood, petrochemicals and pulp mills (Fleeger et al. 2003; Mukherjee et al. 1990). These common water pollutants associated with a wide variety of organic chemicals (Gad, Saad 2008). In soils, phenols can exist in a dissolved form that can move freely in the soil solution, in a sorbed form which reversibly binds to soil particles or proteins, and in a polymerized form consisting of humic substances (Hättenschwiler, Vitousek 2001; Freeman et al. 2001; Rovira, Vallejo 2002).

Some phenols are formed by natural processes, e.g., the formation of phenol and $p$ cresol during organic-matter decomposition or the synthesis of chlorinated phenols by fungi and plants (Swarts et al. 1998). Lignin-sourced macromolecules, a major component of vitrinite macerals, are widespread in sedimentary organic matter, particularly coals of kerogen III type. The major chemical structural elements in vitrinites are simple phenols with a high contribution of para alkyl-substituted derivatives (Killops, Killops 2005; Iglesias et al. 2000). Lignin is a macromolecular polyphenolic compound originating from the cell walls of vascular plants; it is formed by condensation reactions (involving dehydrogenation and dehydration) between three main building blocks, namely, coumaryl-, coniferyl- and sinapyl alcohols (Hedges, Ertel 1982; Killops, Killops 2005). Phenol and alkyl phenols are the most prominent products of the degradation of both lignin itself and lignin-derived macromolecules in coal (Saiz-Jimenez, De Leeuw 1985; Hatcher et al. 1992; Iglesias et al. 2002). Alkylphenols associated with short-chain $\left(\mathrm{C}_{1}-\mathrm{C}_{3}\right)$ methoxy-substituted alkylphenols, are typical pyrolysis products of unaltered- or weakly-altered lignin that reflect a terrigenous input (Martin et al. 1979; Obst 1983; Garcette-Lepecq et al. 2000; Faure et al. 2004). The series of methoxyphenols is formed from the thermal breakdown of lignin, and monosaccharide derivatives from cellulose. These derivatives of syringyl alcohol bound in lignin and include mainly syringic acid, syringyl acetone, acetosyringone and the dimer species disyringyl (Simoneit et al. 1993; Simoneit 2002; Ré-Poppi, SantiagoSilva 2002; Simoneit et al. 2007). In addition, angiosperm lignin contains high concentrations of the sinapyl- as well as coniferyl alcohol subunits which are the precursors to the syringol- and methoxyphenol degradation products from oxidation or pyrolysis (Hedges, Ertel 1982). The alkylphenols mainly arise from higher plants (Damsté, de Leeuw 1995). The formation of 2,4-dimethylphenol is believed to occur during the transformation of catechol-like structures into phenolic structures which takes place, in a selective manner, during coalification from lignite to subbituminous coal (Hatcher et al. 1988, 1989). Fabiańska and Kurkiewicz (2013) showed that in the pyrolysates of detrital lignites, phenol 
and its para substituted derivatives such as $p$-cresol, $p$-vinylphenol, and $p$-ethylphenols predominate, indicating lignin structures of herbaceous plants (mostly monocotyledons) that are rich in coumaryl-alcohol units (Hatcher, Clifford 1997).

\section{Study areas}

In the USCB, the coals range from subbituminous- to high-volatile bituminous coals (Kotarba et al. 2002). The general features of the organic matter contained in the coal waste are similar to those of the bituminous coals (Fabiańska et al. 2013). Most of the organic matter was deposited in an estuarine/deltaic environment with normal- to low-water levels. The coals are early matured with similar vitrinite reflectance, and thermal maturity corresponding to early- and medium catagenesis (Fabiańska et al. 2013).

The study area, situated in the Rybnik Industrial Region, comprises four coal waste dumps and a river highly polluted by coal mining and processing (Fig. 1).

1. The coal-waste dumps in Szczygłowice (ca 2.1 million tonnes of waste) and Trachy (ca 47.5 million tonnes) have been used since 1963. They are located along the Valley of Bierawka River. In the case of the Szczyglowice dumps, there has been significant material transport into the Bierawka River from the steep slopes.

2. The Czerwionka-Leszczyny dump is forested and consists of three cones $(\sim 100$ meters high). Intensive pseudo-fumarolic activity occurs on the top of the highest steep cone; gas vents on the surface are surrounded by sulphate crusts and puddles of bitumen (Parafiniuk, Kruszewski 2010). The thermal activity, which has continued for more than 30-40 years, is currently waning (Nádudvari 2014).

3. The Rymer dump is closed at present. The original waste material was essentially burnt out. From 1994-1999, the cones were redeveloped and spread out with additional coalwaste materials. However, as the original burnt-out material was hot, burning restarted in this added coal waste (Tabor 2002). Around the turn of the XXI Century, the surface of this dump was covered by concrete panels to block air access. Despite these, the selfheating intensified. Finally, the panels were removed from the western part. Today, heating occurs mostly on the eastern slope still covered by panels. Bitumen leaches out through cracks in these (Misz-Kennan et al. 2013).

4. The Bierawka River is a tributary of the upper part of the Odra River in southern Poland. Mine drainage has led to increasing sulphate-, sodium- and chloride concentrations in the water (Sracek et al. 2010). The period around 1800 was one of local industrial development based on local- and imported iron ores, charcoal production and hard coal exploitation (Klimek et al. 2013). The influence of coal mining and processing, and coking plants, is clearly evident in the river sediments; black layering is defined by mixtures of fine coal and sediment along the entire river course (Nádudvari, Fabiańska 2015). The river also passes by two coal-waste dumps (Szczygłowice, Trachy; Fig. 1). 


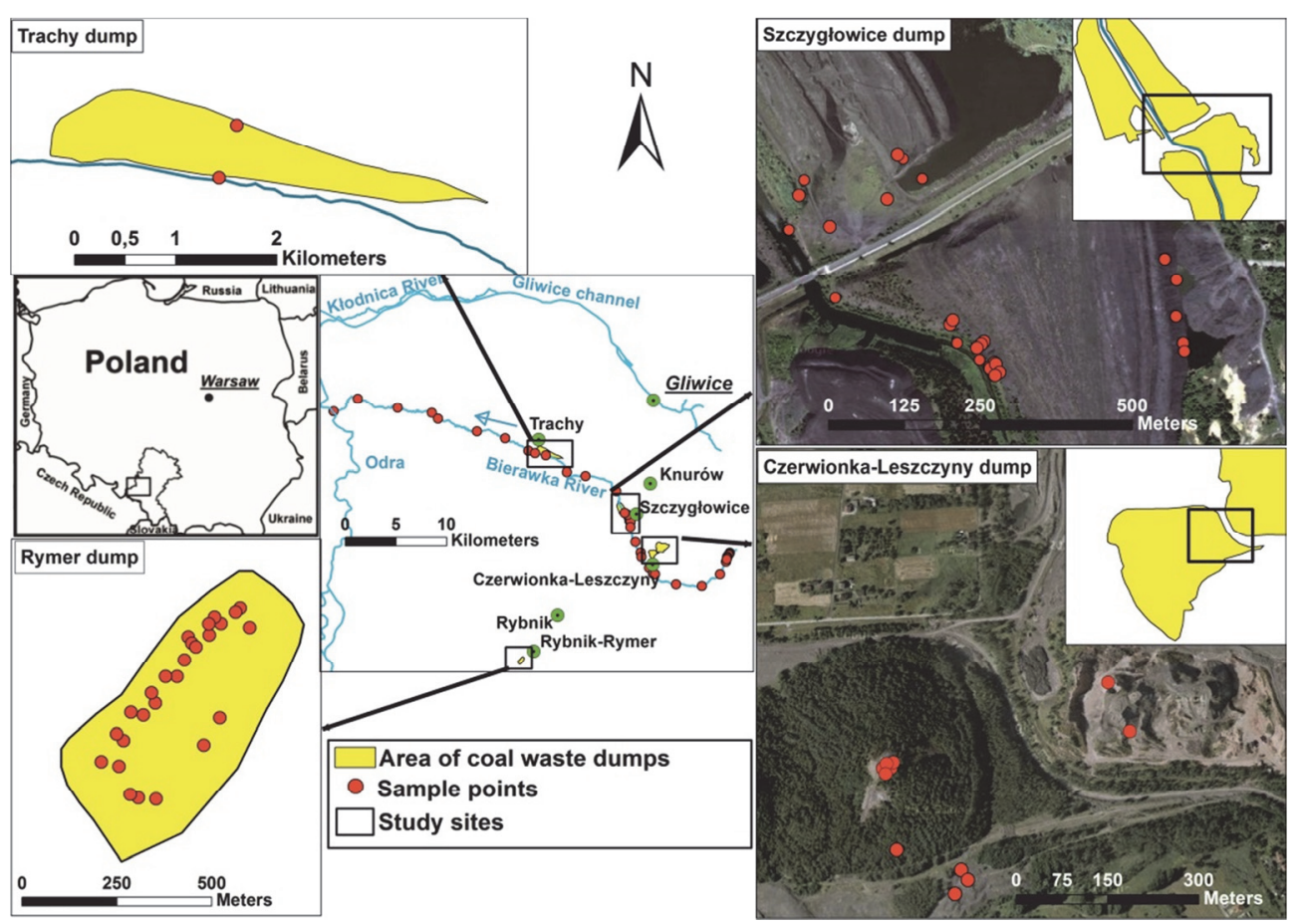

Fig. 1. The locations of the sites studied together with sampling points.

\section{Methodology and materials}

Samples of self-heated- and water-washed waste, fresh coal waste and river sediment from the bank of the Bierawka River were collected. For each sample, ca 1-2 kg material was taken at a depth of 5-10 cm. In total, 234 sample extracts were analyzed by gas chromatography-mass spectrometry (GC-MS). The sample set comprises: (a) Freshlydumped (a few weeks before) coal waste taken from the Szczygłowice dump (7 samples) and from the Trachy dump (2 samples). (b) Samples from erosion gullies taken from the Czerwionka-Leszczyny (4 samples) and Szczygłowice dumps (36 samples). (c) 12 water samples from the Szczygłowice dump collected, after heavy rains, from gullies that enter the Bierawka River. (d) Self-heated samples from the Czerwionka-Leszczyny dump (11 samples) and from the Rymer dump (85 samples) and (e) 47 sediments and 31 water samples collected from the entire course of the Bierawka River.

The samples of coal-waste and sediments were dried at room temperature $\left(\mathrm{ca} 22^{\circ} \mathrm{C}\right)$ for ca 5 days and powdered in a rotary mill to $0.2 \mathrm{~mm}$ grain size. Each sample was cleaned manually to remove surface contamination (roots, boughs, grass). After powdering, 15-20 g of each sample was extracted in dichloromethane (DCM) in a Dionex 350 apparatus dedicated to accelerated solvent extraction.

For water samples, ca $1 \mathrm{dm}^{3}$ was taken at each sampling point. Several samples, mostly waters from erosion gullies on the Szczygłowice dump had to be filtered once as they 
contained a light fraction of sediment. Dissolved organic compounds were isolated using solid phase extraction (SPE) on $60 \mathrm{ml} \mathrm{C}_{18}$ PolarPlus columns (BAKERBOND) with $500 \mathrm{mg}$ of solid phase bonded on silica gel $(40 \mu \mathrm{m}$ APD, $20 \AA)$. About $0.5 \mathrm{dm}^{3}$ of water mixed with isopropanol (analytical) in the ratio 50:3 (vol.) was passed through the conditioned columns. Adsorbed organic compounds were eluted with a mixture of dichloromethane (DCM) and hexane.

The extracts were not separated into different compound groups prior to GC-MS analyses due to the very low extractability of some of the samples. All extracts (water, coal waste and sediments) were analyzed on an Agilent 7890A gas chromatograph with $\mathrm{J} \& \mathrm{~W}$ HP-5MS, DB-5, DB-35 and DB-17MS columns coupled to a 5975C XL MDS mass spectrometer. Conditions were as follows: carrier gas, $\mathrm{He}$; temperature programs: $50^{\circ} \mathrm{C}$ (2 min) to $175^{\circ} \mathrm{C}$ at $10^{\circ} \mathrm{C} / \mathrm{min}$, to $225^{\circ} \mathrm{C}$ at $6^{\circ} \mathrm{C} / \mathrm{min}$ and to $300^{\circ} \mathrm{C}$ (held for $20 \mathrm{~min}$ ) at $4^{\circ} \mathrm{C} / \mathrm{min}$. The spectrometer was operated in the electron ionisation (EI) mode $(70 \mathrm{eV}$, full scan) and scanned from $\mathrm{m} / \mathrm{z}$ 50-650. Compounds were identified by using their mass spectra, comparison of peak retention times with those of standard compounds, interpretation of MS fragmentation patterns and literature data (Philp 1985; The Wiley/NBS Registry of Mass Spectral Data 2000). Phenols were manually integrated (peak areas) using their mass spectra $(94,108,122,136,150 \mathrm{~m} / \mathrm{z})$. The results were semiquantitatively analysed to assess the relative percentage of phenols in each sample. Thus, each peak areas of the chromatogram (together with phenols) had to be manually integrated. Then, each peak areas were compared to the total peak area of the whole chromatogram (calculated in percentages). Later, the assessed phenol percentages were summarised to see how much of the entire chromatogram contained only phenols.

\section{Results and discussion}

The samples contain a wide range of phenols represented by phenol, $\mathrm{C}_{1}$-phenols (methylphenols); $\mathrm{C}_{2}$-phenols (dimethyphenol, and ethyphenols) and lower relative percentages of $\mathrm{C}_{3}$-phenols (trimethylphenols, methyethylphenols, propylphenols) and $\mathrm{C}_{4}$-phenols (tert-butylphenols, dimethylethylphenols, methylpropylphenols, 4-vinylmethoxilphenols) as shown on Figure 2. The exact distribution of phenols can be influenced by many factors, e.g., organic-matter origin and its rank (Hatcher et al. 1992; Skręt et al. 2010).

\subsection{Phenols released by organic-matter oxidation and water washing}

Generally, the fresh coal wastes contain 0.66 rel.\% of phenols, mostly dimethylphenols $\left(\mathrm{C}_{2}\right.$-phenols) and, e.g., 3-ethyl-5-methylphenol $\left(\mathrm{C}_{3}\right.$-phenols) as shown in Table 1 . The presence of phenols in fresh coal waste can be explained by the findings of Swann and Evans (1979) on brown coal oxidation; oxygen gained in the solid phase during oxidation accounts for increased amounts of carboxyl-, carbonyl- and phenolic groups. Short storage times eliminated the possibility of any leaching by water. In addition, bacterial and fungal degradation of vitrinite particles in coal waste can also release phenols (Orem et al. 2010; Haider et al. 2013). 

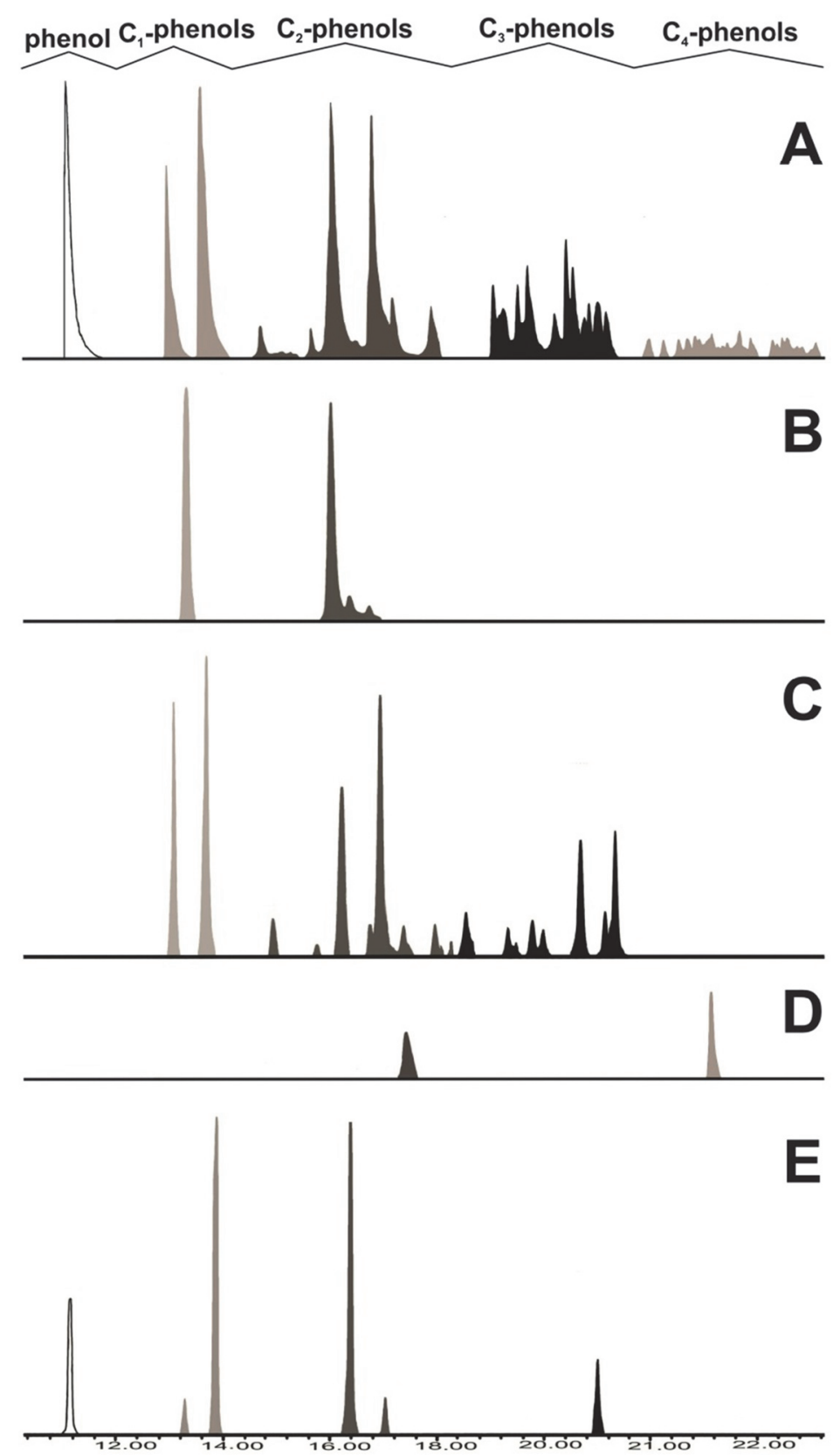

Fig. 2. Representative chromatograms for phenols from the different sample groups. A: Fresh coal wastes. B: Samples from erosion gullies from Szczygłowice- and Czerwionka-Leszczyny dumps. C: Czerwionka-Leszczyny self heated samples. D: Water samples from Bierawka River. E: River sediments from Bierawka River. (Phenol: m/z 94. C $1_{1}$-phenols: m/z 108. $\mathrm{C}_{2}$-phenols: m/z 122. $\mathrm{C}_{3^{-}}$ phenols: $\mathrm{m} / \mathrm{z}$ 136. $\mathrm{C}_{4}$-phenols: $\mathrm{m} / \mathrm{z}$ 150) 
Table 1. The distribution of relative percentage contents and most common phenol compounds in the analysed sample groups. Identification of phenols was made by comparison of their mass spectra and peak retention times with those of standard compounds, and using literature data. The relative average $\%$ contents represent the summarised phenols of each chromatogram in each sample group.

\begin{tabular}{|c|c|c|c|c|}
\hline Analysed sample groups & The most common phenols & $\begin{array}{l}\text { Relative } \\
\text { average } \% \\
\text { contents }\end{array}$ & $\begin{array}{l}\text { Number of } \\
\text { samples which } \\
\text { contained } \\
\text { phenols }\end{array}$ & $\begin{array}{l}\text { Number of } \\
\text { samples, where } \\
\text { phenols were } \\
\text { absent }\end{array}$ \\
\hline $\begin{array}{l}\text { Fresh coal wastes } \\
\text { (Szczygłowice -and } \\
\text { Trachy dumps) }\end{array}$ & $\begin{array}{l}\text { 2,3-dimethylphenol (m/z 122); } \\
\text { 2,4-dimethyphenol (m/z 122); } \\
\text { 2,6-dimethylphenol (m/z 122); } \\
\text { 3-ethyl-5-methylphenol (m/z 136) }\end{array}$ & 0.66 & 8 & 0 \\
\hline $\begin{array}{l}\text { Samples from erosion } \\
\text { gullies (Szczygłowice - } \\
\text { and Czerwionka- } \\
\text { Leszczyny dumps) }\end{array}$ & $\begin{array}{l}\text { 3-methylphenol (m/z 108); } \\
\text { 4-methylphenol (m/z 108); } \\
\text { 2,4-dimethyphenol (m/z 122) }\end{array}$ & 0.35 & 4 & 36 \\
\hline $\begin{array}{l}\text { Water samples from } \\
\text { gullies of coal waste } \\
\text { (Szczygłowice dump) }\end{array}$ & 4-methylphenol (m/z 108) & 0.02 & 1 & 11 \\
\hline $\begin{array}{l}\text { Self-heated samples from } \\
\text { Czerwionka-Leszczyny } \\
\text { dump }\end{array}$ & $\begin{array}{l}\text { 2-methylphenol (m/z 108); } \\
\text { 4-methylphenol (m/z 108); } \\
\text { 2,3-dimethylphenol (m/z 122); } \\
\text { 2,4- dimethylphenol (m/z 122); } \\
\text { 2,6- dimethylphenol (m/z 122); } \\
\text { 2,5-dimethyphenol (m/z 122) }\end{array}$ & 1.17 & 8 & 3 \\
\hline $\begin{array}{l}\text { Self-heated samples from } \\
\text { Rymer dump }\end{array}$ & $\begin{array}{l}\text { phenol (m/z 94); } \\
\text { 2-methylphenol (m/z 108); } \\
\text { 3-methylphenol (m/z 108); } \\
\text { 4-methylphenol (m/z 108); } \\
\text { 2-ethylphenol (m/z 108); } \\
\text { 3-ethylphenol (m/z 108); } \\
\text { 2,3-dimethylphenol (m/z 122); } \\
\text { 2,4-dimethyphenol (m/z 122); } \\
\text { 2,5-dimethyphenol (m/z 122); } \\
\text { 2,6- dimethylphenol (m/z 122); } \\
\text { 3,4-dimethylphenol (m/z 122); } \\
\text { 3,5-dimethylphenol (m/z 122); } \\
\text { 2-ethyl-6-methylphenol (m/z 136); } \\
\text { 3-ethyl-5-methylphenol (m/z 136); } \\
\text { 2,3,5-trimethylphenol (m/z 136); } \\
\text { 2,4,6-trimethylphenol (m/z 136); } \\
\text { 2-methoxy-4-vinylphenol (m/z 150); } \\
\text { phenol, 4-(1-methylpropyl) (m/z 150) }\end{array}$ & 13.3 & 71 & 14 \\
\hline $\begin{array}{l}\text { River sediments from the } \\
\text { Bierawka River }\end{array}$ & $\begin{array}{l}\text { phenol (m/z 94); } \\
\text { 2-methylphenol (m/z 108); } \\
\text { 4-methylphenol (m/z 108); } \\
\text { 2,4- dimethylphenol; (m/z 122) }\end{array}$ & 0.23 & 34 & 13 \\
\hline $\begin{array}{l}\text { River water samples from } \\
\text { the Bierawka River }\end{array}$ & $\begin{array}{l}\text { 2-dimethylphenol (m/z 122); } \\
\text { 3-(1,1-dimethylethyl)phenol (m/z 150); } \\
\text { 4-(1,1-dimethylethyl)phenol (m/z 150) }\end{array}$ & 0.07 & 19 & 12 \\
\hline
\end{tabular}


Of 40 gully samples from Szczygłowice and Czerwionka-Leszczyny, only four contain some phenols (Table 1), e.g., 3-methylphenol, 4-methylphenol, and 2,4-dimethyphenol (on aver 0.35 rel.\%). Furthermore, of twelve water samples taken after heavy rain from gullies on the Szczygłowice dump, only one contains phenols (4-methylphenol; 0.02 rel.\%), because of the intensive water washing. As phenols are very soluble in water, they are easily leached and potentially washed into dump interiors or surroundings (Faksness, Brandvik 2008; Misz-Kennan 2010; Misz-Kennan, Fabiańska 2011, 2010; Skręt et al. 2010). In addition, in the Bierawka River sediments, the average relative percentage of phenols is elevated in the interval between the Szczygłowice dump and the Odra River $(0.34 \%)$ as compared to the interval between the dump and the river source $(0.11 \%)$; leaching from the Szczygłowice dump is indicated. Around the dump, several soil-water lakes reflect subsidence due to undergound mining (Pelka-Gosciniak et al. 2008; Wojciechowski 2006). Associated with the mining activities, the river channel has become wider with the water level reaching the base of the dumps. Thus, the leaching of phenols is now even more likely.

\subsection{The presence of phenols in sediment and river waters}

Thirty-four sediment samples from the river contained phenols such as $\mathrm{C}_{1^{-}}$and $\mathrm{C}_{2}$-phenols (on average, $0.23 \mathrm{rel} \% \%$; Table 1). The phenols in the river sediments show a similar pattern to those in the coal waste (Fig. 3); the presence of coal and coke particles is the reason.

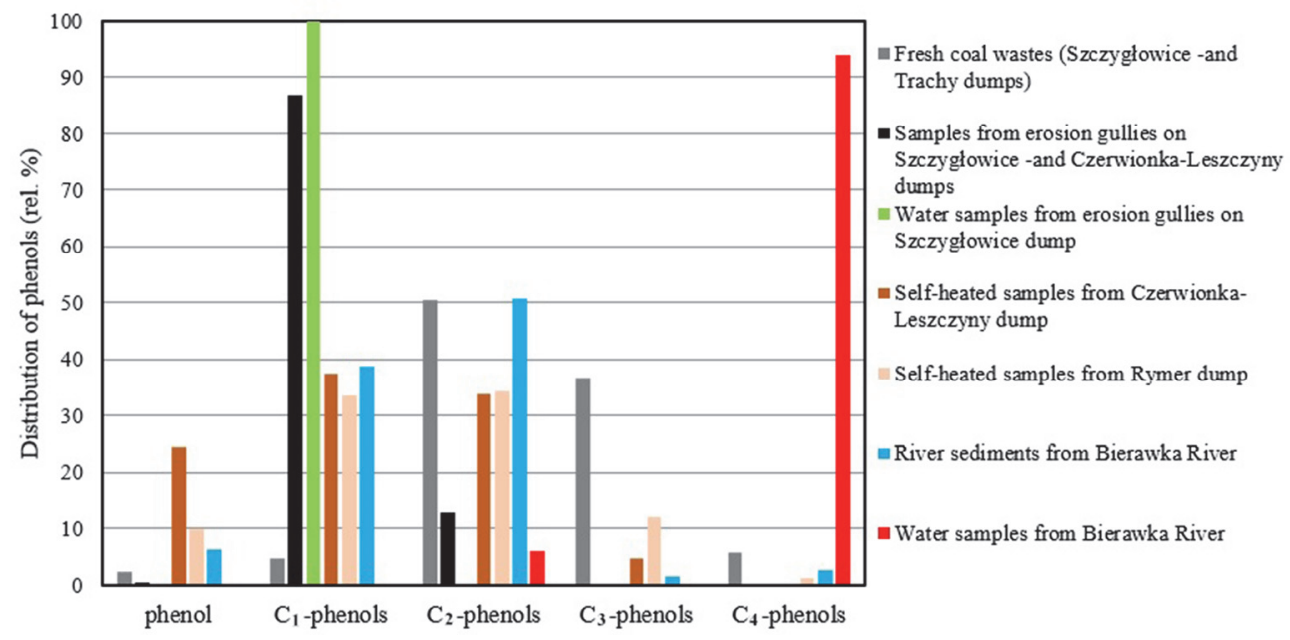

Fig. 3. Summarised relative percentages in the different sample groups compared to the total amount of phenol compounds.

The primary origin of the sediment-hosted coaly material is related not only to the coal processing but also to the dumping of a thousand tons of ash with unburned coal particles from an old glass factory near the river source. This material has been redeposited along the 
entire river course. Hard-coal processing features (crushing-washing) are evident in larger coal fragments. Intensive erosion of the steep slopes of the Szczygłowice coal-waste dump also transferred significant amounts of organic matter into the river (Nádudvari, Fabiańska 2015).

Phenols in river sediments may originate from factories, coke production or from the fungal- and/or bacterial degradation of the coaly sediments and other organic matter such as pine needles, leaves, grass and wood (Saiz-Jimenez, De Leeuw 1985; Faure et al. 1999; Orem et al. 2010; Haider et al. 2013). Methylphenols occur in high concentrations (up to several grams per kilogram) in coal tar. The representatives of methylphenols are cresols that form three isomers - ortho, meta and para-cresol. In addition, $O$-cresols, dimethylphenol and 2,4,6- trimethylphenol are also formed during coal- and gasoline combustion (Ioppolo-Armanios et al. 1995; McBrain et al. 1996). This may explain the presence of $\mathrm{C}_{1}$ and $\mathrm{C}_{2}$-phenols in the ash-bearing Bierawka sediments.

Nineteen river-water samples contained phenols (on average, 0.07 rel. \%). The most common are $\mathrm{C}_{4}$-phenols (Table 1, Fig. 3). Their origin is probably industrial or domestic. Moreover, phenols such as 3-(1,1-dimethylethyl)-4-methoxyphenol are used in cosmetics, rubber, pesticides, fungicides and bactericides (SAC 2010).

\subsection{Phenol released from self-heated coal wastes}

The extracts of the self-heated coal-waste samples contain the highest percentages of phenols; those from Czerwonka-Leszczyny $1.17 \%$ (on average) and those from Rymer $13.3 \%$, the highest of all. Phenol, $\mathrm{C}_{1}$-phenol, and $\mathrm{C}_{2}$-phenols are the most abundant compounds, but heavier $\mathrm{C}_{3}-$ and $\mathrm{C}_{4}$-phenols are present in smaller quantities (Fig. 3). As these compounds are released from vitrinite as a result of its thermal destruction, they may represent the relatively early stages of self-heating (Skręt et al. 2010). On the Rymer dump, as the current self-heating only started after the remediation of 15-20 years ago, phenols are present in especially significant amounts. Here, leaching and evaporation may have been limited by the covering of concrete panels (Nádudvari, Fabiańska 2016). In contrast, heating has continued for more than 30-40 years on the Czerwionka-Leszczyny dump. In this case, phenols are likely to have been destroyed by combustion, leached, and/or have evaporated.

High contents of phenols reflect the intensity of the thermal changes due to heating (Misz-Kennan, Fabiańska 2011). In addition, abundant phenols (with domination of $\mathrm{C}_{1}-\mathrm{C}_{2}$ types) typify expelled bitumen mixed in with the waste. Furthermore, highly thermallyaffected waste (mostly burned-out material) containing the lowest amounts of phenols (with domination of $\mathrm{C}_{2}$ type) reflect the total destruction of vitrinites, and the ease of phenol leaching and evaporation (Nádudvari, Fabiańska 2016).

\section{Conclusions}

1. Fresh coal waste can be a source of phenols originating from bacterial/fungal degradation, and the oxygenation of vitrinite particles. These highly toxic pollutants should be prevented from migrating out into dump surroundings. 
2. On the coal-waste dumps, gully- and water samples contain lesser quantities of phenols due to intensive water-washing. Leaching from the Szczygłowice dump contributes to elevated phenol contents in the Bierawka River downstream from the dump.

3. The presence of identified phenols, notably $\mathrm{C}_{1}-\mathrm{C}_{2}$ phenols, in the sediments of the Bierawka River draws attention to what is likely a widespread phenomenon associated with coal processing. For example, similar environmental issues may characterize rivers in other coal mining districts in the region, e.g., the Kłodnica and Ruda Rivers. Phenols in river sediments may also reflect bacterial- or fungal decay of coaly matter in the sediments.

4. The fact that the highest contents of phenols (phenol, $\mathrm{C}_{1^{-}}$and $\mathrm{C}_{2}$ ) derive from the thermal destruction of vitrinite is especially significant where self-heating is present on a coal-waste. Phenols as highly-toxic pollutants released from coal waste and by the coal processing industry should be given serious attention, especially in the environs of dumps sited close to urban areas.

Acknowledgement. The authors are grateful to Dr Padhraig Kennan (University College Dublin) for language corrections.

\section{References}

Clayton, G. D., \& Clayton, F. E. (1994). Patty's Industrial Hygiene and Toxicology (4 ed.). John Wiley \& Sons Inc. New York, Vol. 2A, 132 p.

Damsté, J. S. S., \& de Leeuw, J. W. (1995). Comments on "Biomarkers or not biomarkers. A new hypothesis for the origin of pristane involving derivation from methyltrimethyltridecylchromans (MTTCs) formed during diagenesis from chlorophyll and alkylphenols" from M. Li, S. R. Larter, P. Taylor, D. M. Jones, B. Bowler and M. Bjørey. Organic Geochemistry, 23, 1085-1087.

Fabiańska, M. J., Ćmiel, S. R., \& Misz-Kennan, M. (2013). Biomarkers and aromatic hydrocarbons in bituminous coals of Upper Silesian Coal Basin: Example from 405 coal seam of the Zaleskie Beds (Poland). International Journal of Coal Geology, 107, 96-111. DOI:10.1016/j.coal.2012.08.003.

Fabiańska, M.J., \& Kurkiewicz, S. (2013). Biomarkers, aromatic hydrocarbons and polar compounds in the Neogene lignites and gangue sediments of the Konin and Turoszów Brown Coal Basins (Poland). International Journal of Coal Geology, 107, 24-44. DOI:10.1016/j.coal.2012.11.008.

Faksness, L. G., \& Brandvik, P. J. (2008). Distribution of water soluble components from oil encapsulated in Arctic sea ice: Summary of three field seasons. Cold Regions Science and Technology, 54(2), 106-114. DOI:10.1016/j.coldregions.2008.03.006.

Faure, P., Elie, M., Mansuy, L., Michels, R., Landais, P., \& Babut, M. (2004). Molecular studies of insoluble organic matter in river sediments from Alsace-Lorraine (France). Organic Geochemistry, 35(2), $109-122$. DOI:10.1016/j.orggeochem.2003.10.008.

Faure, P., Landais, P., Elie, M., Kruge, M., Langlois, E., \& Ruau, O. (1999). Application of organic geochemistry techniques to environmental problems. In J., Berthelin, P-M., Huang, J.-M., Bollag, F. Andreux, (Eds.), Effects of Mineral-Organic-Microorganism Interactions on Soil and Fresh Water Environments (pp 119-131). Plenum Publishing Company, London.

Fleeger, J. W., Carman, K. R., \& Nisbet, R. M. (2003). Indirect effect of contaminants in aquatic ecosystems. Science of the Total Environment, 317, 207-233. DOI:10.1016/S0048-9697(03)00141-4.

Freeman, C., Evans, C. D., Monteith, D. T., Reynolds, B., \& Fenner, N. (2001). Export of organic carbon from peat soils. Nature, 412, 785. DOI:10.1038/35090628.

Gad, N. S., \& Saad., A. S. (2008). Effect of Environmental Pollution by Phenol on Some Physiological Parameters of Oreochromis niloticus. Global Veterinaria, 2(6), 312-319.

Garcette-Lepecq, A., Derenne, S., Largeau, C., Bouloubassi, I., \& Saliot, A. (2000). Origin and formation pathways of kerogen-like organic matter in recent sediments of the Danube delta (northwestern Black Sea). Organic Geochemistry, 31, 1663-1683. DOI:10.1016/S0146-6380(00)00100-5. 
Haider, R., Ghauri, M. A., SanFilipo, J. R., Jones, E. J., Orem, W. H., Tatu, C. A., Akhtar, K., \& Akhtar, N. (2013). Fungal degradation of coal as a pretreatment for methane production. Fuel, 104, 717-725. DOI:10.1016/j.fuel.2012.05.015.

Hatcher, P. G., \& Clifford, D.J. (1997). The organic geochemistry of coal: from plant materials to coal. Organic Geochemistry, 27, 251-274. DOI:10.1016/S0146-6380(97)00051-X.Hatcher, P. G., Faulon, J. L., Wenzel, K. A., \& Cody, G. D. (1992). A structural model for ligninderived vitrinite from high-volatile bituminous coal (coalified wood). Energy \& Fuels, 6, 813-820.

Hatcher, P. G., Lerch, H. E. I., \& Verheyen, T. V. (1989). Organic geochemical studies of the transformation of gymnospermous xylem during peatification and coalification to subbituminous coal. International Journal of Coal Geology, 13, 65-97.

Hatcher, P. G., Lerche, H. E. I., Kotra, R. K., \& Verheyen, T. V. (1988). Pyrolysis g.c-m.s. of a series of degraded woods and coalified logs that increase in rank from peat to subbituminous coal. Fuel, 67, 1069-1075.

Hättenschwiler, S., \& Vitousek, P. M. (2001). The role of polyphenols in terrestrial ecosystem nutrient cycling. Trends in Ecology and Evolution, 15(6), 238-243. DOI:10.1016/S0169-5347(00)01861-9.

Hedges, J. I., \& Ertel, J. R. (1982). Characterization of lignin by gas capillary chromatography of cupric oxide oxidation products. Analytical Chemistry, 54, 174-178.

Iglesias, M. J., del Rio, J. C., Laggoun-Défarge, F., Cuesta, M. J., \& Suárez-Ruiz, I. (2002). Control of the chemical structure of perhydrous coals; FTIR and Py-GC/MS investigation. Journal of Analytical and Applied Pyrolysis, 62, 1-34. DOI: 0.1016/S0165-2370(00)00209-6.

Iglesias, M. J., Jimeánez, A., del Rõáo, J. C., \& Suárez-Ruiz, I. (2000). Molecular characterisation of vitrinite in relation to natural hydrogen enrichment and depositional environment. Organic Geochemistry, 31, 1285-1299. DOI:10.1016/S0146-6380(00)00086-3.

Ioppolo-Armanios, M., Alexander, R., \& Kagi, R. (1995). Geosynthesis of organic compounds: I. Alkylphenols. Geochimica et Cosmochimica Acta, 59, 3017-3027. DOI:10.1016/0016-7037(95)80001-8.

Killops, S., \& Killops, V. (2005). Introduction to Organic Geochemistry (Second Edition) Blackwell publishing, pp 45-300.

Klimek, K., Górska, W., \& Woskowicz-Slezak, B. (2013). Bierawka - Odra confluence: A record of sandy-bed river transformation under human impact. Abstract Book and Field Guide (ed.) Kalicki, T., Krupa, J., (conference material) Geoarcheology of river valleys 13-15 May, Kielce-Suchedniów (Poland).

Kotarba, M. J., Clayton, J. L., Rice, D. D., \& Wagner, M. (2002). Assessment of hydrocarbon source rock potential of Polish bituminous coals and carbonaceous shales. Chemical Geology, 184, 11-35. DOI:10.1016/S0009-2541(01)00350-3.

Martin, F., Saiz-Jimenez, C., \& Gonzalez-Vila, F. J. (1979). Pyrolysis-gas chromatography-mass spectrometry of lignin. Holzforschung, 33, 210-212.

McBrain, A., Senire, E., Patersona, A., Duplessis, C. H., \& Watson-Craiene, A. (1996). Bioremediation of soil contaminated with 4-chloro-2-methylphenoxyacetic acid (MC PA): essential laboratory studies. South African Journal of Science, 92, 426-430.

Michałowicz, J., \& Duda, W. (2007). Phenols - Sources and Toxicity. Polish Journal of Environmental Studies, 16, 347-362.

Misz-Kennan, M. (2010). Thermal alterations of organic matter in coal wastes from Upper Silesia, Poland. Mineralogia, 3-4, 105-236. DOI: 10.2478/v10002-010-0001-4.

Misz-Kennan, M., Ciesielczuk, J., \& Tabor, A. (2013). Coal-Waste Dump Fires of Poland. (Chapter 15) In: G.B., Stracher, A., Prakash, \& E.V. Sokol (Eds.), Coal and Peat Fires: A Global Perspective Volume 2 (pp $233-$ 311). Photographs and Multimedia Tours. (ISBN: 0978-0-444-59412-9).

Misz-Kennan, M., \& Fabiańska, M. (2010). Thermal transformation of organic matter in coal waste from Rymer Cones (Upper Silesian Coal Basin, Poland). International Journal of Coal Geology, 81, 343-358. DOI:10.1016/j.coal.2009.08.009.

Misz-Kennan, M., \& Fabiańska, M. J. (2011). Application of organic petrology and geochemistry to coal waste studies. International Journal of Coal Geology, 88, 1-23. DOI:10.1016/j.coal.2011.07.001.

Mukherjee, D., Bhattacharya, S., Kumar, V., \& Moitra, J. (1990). Biological significance of. phenol accumulation in different organs of a murrel, Chamnna punctatus and the common carp Cyprinus carpio. Biomedical and Environmental Science, 3, 337-342.

Nádudvari, Á., \& Fabiańska, M. J. (2015). Coal-related sources of organic contamination in sediments and water samples of Bierawka River (Poland). International Journal of Coal Geology, 152, 94-109. DOI: 10.1016/j.coal.2015.11.006. 
Nádudvari, Á. (2014). Thermal mapping of self-heating zones on coal waste dumps in Upper Silesia (Poland) A case study. International Journal of Coal Geology, 128-129, 47-54. DOI:10.1016/j.coal.2014.04.005.

Nádudvari, Á., \& Fabiańska, M. J. (2016). Use of geochemical analysis and vitrinite reflectance to assess different self-heating processes in coal-waste dumps (Upper Silesia, Poland). Fuel, 181, 102-119. DOI:10.1016/j.fuel.2016.04.129.

Obst, J. R. (1983). Analytical pyrolysis of hardwood and softwood lignins and its use in lignin-type determination of hardwood vessel elements. Journal of Wood Chemistry and Technology, 3, 377-397.

Orem, W. H., Voytek, M. A., Jones, E. J., Lerch, H. E., Bates, A. L., Corum, M. D., Warwick, P. D., \& Clark, A. C. (2010). Organic intermediates in the anaerobic biodegradation of coal to methane under laboratory conditions. Organic Geochemistry, 41, 997-1000. DOI:10.1016/j.orggeochem.2010.03.005.

Parafiniuk, J., \& Kruszewski, Ł. (2010). Minerals of the ammonioalunite_ammoniojarosite series formed on a burning coal dump at Czerwionka, Upper Silesian Coal Basin, Poland. Mineralogical Magazine, 74(4), 731745. DOI: 10.1180/minmag.2010.074.4.731.

Pelka-Gosciniak, J., Rahmonov, O., \& Szczypek, T. (2008). Water reservoirs in subsidence depressions in landscape of the Silesian Upland (Southern Poland), Environmental Engineering, May 22-23, The 7th International Conference on Environmental engineering in Lithuania.

Philp, R. P. (1985). Fossil Fuel Biomarkers. Application and Spectra. Elsevier Science Pub. Co., Inc., New York, NY. 294 pp.

Ré-Poppi, N., \& Santiago-Silva, M. R. (2002). Identification of Polycyclic Aromatic Hydrocarbons and Methoxylated Phenols in Wood Smoke Emitted During Production of Charcoal. Chromatographia, 55, 475-481.

Rovira, P., \& Vallejo, V. R. (2002). Labile and recalcitrant pools of carbon and nitrogen in organic matter decomposing at different depths in soil: an acid hydrolysis approach. Geoderma, 107(1-2), 109-141. DOI:10.1016/S0016-7061(01)00143-4.

SAC (Screening Assessment for the Challenge) (2010). Available fromhttps://www.ec.gc.ca/eseees/default.asp?lang=En\&n=6E4A53B5-1.

Saiz-Jimenez, C., \& de Leeuw, J. W. (1985). Lignin pyrolysis products: Their structures and their significance as biomarkers. Organic Geochemistry, 10, 869-876.

Simoneit, B. R. T. (2002). Biomass burning - a review of organic tracers for smoke from incomplete combustion. Applied Geochemistry 17, 129-162. DOI:10.1016/S0883-2927(01)00061-0.

Simoneit, B. R. T., Rogge, W. F., Mazurek, M. A., Standley, L. J., Hildemann, L. M., \& Cass, G. R. (1993). Lignin pyrolysis products, lignans and resin acids as specific tracers of plant classes in emissions from biomass combustion. Environmental Science and Technology, 27, 2533-2541. DOI: 10.1021/es00048a034.

Simoneit, B. R. T., Bi, X., Oros, D. R., Medeiros, P. M., Sheng, G., \& Fu, J. (2007). Phenols and Hydroxy-PAHs (Arylphenols) as Tracers for Coal Smoke Particulate Matter: Source Tests and Ambient Aerosol Assessments. Environmental Science and Technology, 41, 7294-7302. DOI: 10.1021/es071072u.

Skręt, U., Fabiańska, M. J., \& Misz-Kennan, M. (2010). Simulated water-washing of organic compounds from selfheated coal wastes of the Rymer Cones Dump (Upper Silesia Coal Region, Poland). Organic Geochemistry 41(9), 1009-1012. DOI:10.1016/j.orggeochem.2010.04.010.

Sracek, O., Gzyl, G., Frolik, A., Kubica, J., Bzowski, Z., Gwoździewicz, M., \& Kura, K. (2010). Evaluation of the impacts of mine drainage from a coal waste pile on the surrounding environment at Smolnica, southern Poland. Environmental Monitoring Assessment, 165, 233-254. DOI: 10.1007/s10661-009-0941-6.

Swann, P. D., \& Evans, D. G. (1979). Low-temperature oxidation of brown coal. 3. Reaction with molecular oxygen at temperatures close to ambient. Fuel, 58, 276-80. doi:10.1016/0016-2361(79)90136-4.

Swarts, M., Verhagen, F., Field, J., \& Wijnberg, J. (1998). Trichlorinated phenols from Hypholoma elongatum. Phytochemistry, 49, 203-206. DOI:10.1016/S0031-9422(97)01067-4.

Tabor, A. (2002) Monitoring of coal waste dumps, re-cultivated dumps and other collection sites of Carboniferous waste rocks in the light of many years experience. Proceedings - VII Conference "Long term proecological undertakings in the Rybnik Coal Area”, October 2002 (pp. 131-141). Rybnik, [in Polish], In: Misz-Kennan, M., (2010). Thermal alterations of organic matter in coal wastes from Upper Silesia, Poland. Mineralogia, 41(3-4),105-236.

The Wiley/NBS Registry of Mass Spectral Data (2000) Wiley, New York.

United States Environmental Protection Agency (EPA) (2000) Phenol, from http://www.epa.gov/ttnatw01/hlthef/phenol.html.

Wojciechowski, T. (2006). The Dynamics of Mining Subsidence in Knurow Area in Poland Derived from SAR Interferometry and Topographic Data, European Space Agency - Publications - ESA Sp, 610; P35 FringeWorkshop, Fringe. 